\title{
Measures on Painting Theory Course Teaching Reform in Colleges and Universities
}

\author{
Jiawei Zhang, Yi Wen \\ Xijing University, Xi'an Shaanxi, China
}

Key Words: Painting Theory, Existing Problems, Education Reform, Effective Measures.

\begin{abstract}
The art theory courses have a full-scale influence on the students. They can not only improve the students' professional skills on painting, but also help in cultivating the students to be a thinking and moral comprehensive talent. However, the courses on painting theory in many art schools are not properly paid attention to, and the situation of "attaching importance on skills rather than theories" is still existing. Taking "Painting Theory Course Teaching Reform in Colleges and Universities" as the core point, this thesis will analyze the importance as well as the problems existing in art theory courses and put forward corresponding education reform measures.
\end{abstract}

\section{Introduction}

The teaching and study of professional theories were much valued in traditional education in China's higher education field. However, with the rapid development of Chinese economy and society, more and more practical talents are badly in need, resulting in universities' and colleges' tendency of attaching importance on skills rather than theories. As for the painting major, the reform and innovation of painting theory course teaching should be the juche idea of art education. The neglecting of painting theory courses in teaching has seriously hindered the object of students' integrated development. For many years, China has been continually perform reform and innovation in education field and has had good achievements.

Different from others, painting teaching is quite intuitive, and teaching on both drawing skills and overall layout of painting cannot be separated from art theory. Currently, the painting courses in art academies are mainly divided into theory courses and skill courses. However, many academies are putting emphasis on skill teaching rather than theory teaching, which is not good for the well development of students.

Art theory is absolutely necessary and irreplacable in art education courses. The students should learn the painting theories well no matter if they will emphasize on practical art or become national or world-class authority because "The richness of academic thought of theory knowledge determines your degree of profound professional."

\section{Functions of Art Learning}

The leaning of painting can not only help to realize our art dream, but it can also improve our attainment in the process of learning. First, whole composition is quite important in painting. And at the same time, the depiction on details is also very meticulous. Through the learning of painting, the students' character, social viability can be improved and they will be cultivated to keep careful in observing and dealing with things. Also, they will have initiative in life. Second, painting itself is a kind of art, while the essence of art design is creative thinking. Creative thinking is quite necessary in the learning of creating of paintings. Therefore, the learning of painting art helps cultivate the students' creative thinking and improve their divergent thinking. Third, painting has very strong aesthetic nature. Through the learning of painting, the students' aesthetic judgment can be improved and it is good for them to set up correct values and aesthetic views in life. Four, painting is a group learning course. In the learning process, communications are quite important among students and teachers. Therefore, the students' communication and team working ability are also cultivated. Painting can gather the students to learn and improve together, and it also helps the students to 
appreciate each other.

\section{Importance of Painting Theories}

It helps the students' comprehensive improvement. Many people have one-sided understanding to painting theory teaching, thinking that only content of specialized painting knowledge is involved. In fact, there are rich teaching content in painting theory teaching, including relationships between painting and society as well as painting and human being. Also, there are some psychology and philosophy contents. On the basis of teaching specialized painting knowledge, painting theory teaching aims to cultivate comprehensive and highly-competent talents. Through painting theory teaching, the students can not only learn the specialized painting knowledge, but they will also improve their view on life and values.

It helps the students to improve their painting skills. Painting theory belongs to cultural knowledge, while painting skill belongs to practice. There exists a dialectical relationship between painting theory and painting skill. Painting skill is the basis of painting theory since all the theories are a kind of conclusion of skills. There will not be theory if there is no skill. On the contrary, painting skill needs to be guided by painting theory. Only if you can well understand the painting theory, can you improve your painting skills. In the learning process of painting, the theories helps with the formation of art creation concept, and their skills can be continually improved according to theories.

The painting theory plays a helping role in public course teaching. The establishment of painting theory courses prompts to enrich the professional connotation of public course teaching, with some corresponding borderline science coming into being, for example, painting psychotherapy, which provided the medical domain with a novel therapeutic space, increasing and enriching the medical treatment and treatment. The occurrence of painting therapy is an inevitable phenomenon during the teaching process of painting theory. As early as early 20th century, the painting therapy was applied to psychiatric by the foreign medical field and has achieved very ideal effects. This fully shows that art theory course teaching has great function in public course teaching, and it can derive more borderline science about the fine arts.

\section{Problems Existing in the Teaching of Painting Theories}

The lack of teachers. Teachers are the key point in painting education, and they are the main factor which influences the painting teaching efficiency. Also, the students' artistic career can be influenced by them. In recent years, people are paying more and more attention to painting courses and there are more and more people learning painting. To provide more opportunities to the students, painting major is established in more than 800 universities and colleges in China. However, the number of teachers could not meet the actual requirement. A lot of schools are lack of painting teachings. To solve this problem, a lot of the majors in colleges adopt big group teaching or they will just employ guest teachers. These measures are like a drop in the bucket. When they use group teaching, the teachers can hardly control the class atmosphere, and the quality as well as efficiency would be badly influenced.

The lack of teaching proportion. Currently, painting theory teaching has been attached inefficient importance in many art schools, leading to the fact that painting theory courses only occupies a small proportion of all courses. First, they have arranged inefficient classes for painting theory teaching. There is an obvious difference between the number of painting theory teaching classes and that of other courses. Some colleges are paying too much attention to the training of painting skills, so the painting theory courses only occupies less than one third of skill courses. Also, they have listed Introduction to Art as well as Chinese and Foreign Painting History in cultural courses. Second, they have neglected the score of painting theory courses. Currently, the works show becomes the main point in each year's art examination. The theory score only occupies $20 \%$ of the total score. This will lead to the students' ignorance of painting theory and they will spend less time in painting theory courses. 
The teaching method is not flexible. Teaching method is also one of the important components in painting theory teaching. The selection of teaching method plays an absolute role in the teaching quality. Currently, the teaching method is too simplex. In the teaching process of painting theory, the teachers will only try to ask the students to memorize the knowledge points no matter if they understand or not. In any courses, this method is not advisable. The class atmosphere won't be alive if this kind of teaching method is adopted. The class will become much more boring.

\section{Measures on Teaching Reform of Painting Theory Course}

To develop more teachers. The first step of painting theory teaching course reform is to reinforce the quantity of teachers. First, the number of teachers should be increased. The number of teachers in painting majors can be increased so that the other teachers will have less pressure. Also, when hiring teachers, the quality should be guaranteed. Second, teacher's ethics and characteristics should be strengthened. Among all the painting teachers, there are also some irresponsible and not hard-working ones. As for this kind of situation, the schools can carry out ideological education work to the teachers to let them know the importance of imparting knowledge and educating people. When necessary, rewards and punishment should be carried out. The students' scores can also be used as a scaleplate when awarding or punishing. Third, the teachers should change their teaching concept. A lot of teachings have overlooked the importance of painting theory teaching and denied the guiding value of painting theory. The schools can carry out trainings for teachers on specialized painting theory, getting the teaching to pay more attention to painting theory teaching through the way of autonomic research.

To adjust courses. In China's high education field, the arrangement of painting skills class and theory class hae been contradictory with unreasonable proportion. This kind of unreasonable arrangement has seriously influenced the development of specialized painting teaching, which is not developed in a way suited to the rapid and stable development of China's economic society. Therefore, reform and innovation should in introduced to effectively adjust the proportion of painting skill courses and painting theory courses, thus to meet the society's needs to conduct coordinated development of advancing with The Times.

First of all, we should have a clear thought of the goal and method on painting education. We should fully realize that theory is the basis of the formation of all subjects. There will be no subject if there is no theory. All the subjects should have their own theory to support themselves, playing the role of architecture and philosophy foundation. Therefore, creative course arrangement should come into being. Second, we should reasoningly deal with the dialectical relationship between painting theory and painting skills. We must realize that skill is the basis of theory, and theory plays a guidance role in skill. The learning of theory courses is the soul for skill practices. Through the leaning of painting theory, the mind will be emancipated, the thinking broadened and the painting techniques will be guided.

To make the teaching method diverse. In the teaching process of painting theory, a lot of teachers relies heavily on books and just repeat what the book says. In order to active classroom atmosphere, art theory teachers must enrich art theory course teaching modes. Specific measures are as follow. First, the teachers can exhibit their own works. Paintings are of strong intuition. The theory will not be that persuasive if the teachers only teach the theories without works show. After the explanation on theories, the teachers can show their own works to further illustrate. Through the showing of their own works, the teachers can prove the validity of the painting theory. Second, the teachers can paint from nature to illustrate the theory. In the teaching process of painting theory, painting from nature is the most efficient method. While explaining the theories, the teachers can paint at the same time. Through site creating, the teachers can ask the students to watch and get them understand the painting theories better. 


\section{Conclusion}

Currently, painting theory courses have become the standard configuration of the art schools, For the students, the painting theory is the most basic, while important course. Painting theory course is an inalienable part in painting education. The painting theory not only derives from painting practice, but also guides practice. For the students, if there is a lack of painting theory courses in painting education, the guiding ideology is lost, too. In consideration of the importance of painting theory, the strengthening of painting theory courses has become the inevitable trend of painting education.

\section{Acknowledgment}

Education Reform Project of Xijing University: Professional Garment Drawing Digital Teaching Reform of Costume Design Major, Project Number: JGYB1637.

\section{References}

[1] J.H. Yang: Studying the Animation Specialty Teaching Reform in Colleges and Universities [J]; Art and Design (Theory) 7th Edition, 2010 (In Chinese)

[2] H.X. Qian: On Art and Design Professional Photography Course Teaching Reform in Colleges and Universities [J] Science and Education (The last edition in the month); 1st Edition, 2011 (In Chinese) 